\title{
Alpha V Beta 1 Inhibitor ATN-161
}

National Cancer Institute

\section{Source}

National Cancer Institute. Alpha V Beta 1 Inhibitor ATN-161. NCI Thesaurus. Code C52185.

A small peptide antagonist of integrin alpha5beta1 with potential antineoplastic activity. AT N-161 selectively binds to and blocks the receptor for integ rin alpha5beta1, thereby preventing integ rin alpha5beta1 binding. This receptor blockade may result in inhibition of endothelial cell-cell interactions, endothelial cell-matrix interactions, angiogenesis, and tumor progression. Integ rin alpha5beta1 is expressed on endothelial cells and plays a crucial role in endothelial cell adhesion and migration. 